\title{
The Discourse Analysis of Discourse Information Function Features in Interest Contention of Business Dispute Settlement Courtroom Discourse: A Discourse Information Perspective
}

\author{
Tingting Guo ${ }^{1,2}$ \\ ${ }^{1}$ School of Foreign Languages, Zhongyuan University of Technology, Zhengzhou, Henan, China \\ ${ }^{2}$ The Postdoctoral Research Station of Chinese Language and Literature, School of Liberal Arts, Zhengzhou \\ University, Zhengzhou, Henan, China \\ Correspondence: Tingting Guo, Zhongyuan University of Technology, No. 41, Middle Zhongyuan Road, \\ Zhengzhou 450007, China. Tel: 86-136-7337-0856. E-mail: 532955649@qq.com
}

\author{
Received: February 27, $2020 \quad$ Accepted: March 18, $2020 \quad$ Online Published: June 29, 2020 \\ doi:10.5539/ass.v16n7p99 \\ URL: https://doi.org/10.5539/ass.v16n7p99
}

\begin{abstract}
Interest contention constitutes the major concern of both conflicting litigants in the courtroom discourses concerning business dispute settlement. This paper, by analyzing the features of discourse information units, studies how the discourse information functions work in the interest contention of courtroom trials concerning business dispute settlement. The present study shows that discourse information functions in interest contention of business dispute settlement can be classified into four types. Based on the previous studies concerning discourse information functions ( $\mathrm{Du}, 2009)$, the present study finds out another new type of discourse information function, namely, the compound category. Moreover, it can be found that the realization of different discourse information functions rely on the use of different information units in the interest contention of the disputing litigants.
\end{abstract}

Keywords: courtroom discourse, discourse information function, Discourse Information Theory (DIT), business dispute settlement, interest contention

\section{Introduction}

Under the influence of various factors, data analysis shows that discourse information displays a variety of features in interest contention in business dispute settlement (Guo, 2019; Guo, Zhao, \& Han, 2019). Du (2009) proposes that there are generally three categories of discourse information functions in courtroom questioning and answering, namely, objective category, subjective category, and expositive category. In order to explore how the discourse information functions work in the interest contention of courtroom discourses concerning business dispute settlement. The present study focuses on the characteristics of discourse information functions in interest contention of courtroom discourses concerning business dispute settlement.

\section{Literature Review}

\subsection{Previous Studies on Business Dispute Settlement}

A prominent feature of the studies on business dispute settlement is that huge amounts of business dispute settlement have been studied in construction industry or engineering project (e.g. Loosemore, Nguyen, \& Denis, 2000; Harmon, 2003; Rubin et al., 1999; Adrian, 1988). Certain amounts of studies concerning business dispute settlement focus on family business disputes' settlement (e.g. Sorenson, 1999). Notwithstanding the enormous number of existing literature on business dispute, relevant studies that are conducted from the perspective of linguistics or communication are on a small scale, there is still great research gap and room to explore this topic from the angle of linguistics or interdisciplinary study.

\subsection{Previous Studies on Discourse Information Theory (DIT)}

$\mathrm{Du}$ (2007) puts forward the linguistic model of information structure of legal discourse, and this is regarded as the core model and framework of Discourse Information Theory (DIT). Du $(2013,2015)$ argues that the information unit is the minimal, integral and meaningful unit that has relatively independent complete meaning and structure. And each sentence in a discourse can be regarded as a proposition. A discourse is a hierarchical 
structure with different levels of information units. According to the tree model of discourse information structure (Du, 2007), the macro-structure of a discourse is hierarchical structure which is comprised of a kernel proposition $(\mathrm{KN})$ and a number of propositions developed under the $\mathrm{KN}$ at lower levels until the bottom layer. Each proposition is the content of an information unit that constitutes the smallest unit of meaning (Du, 2007, 2015). In DIT (Du, 2015), information knots are represented by 15 interrogative words, namely, What Thing (WT), What Basis (WB), What Fact (WF), What Inference (WI), What Disposal (WP), Who (WO), When (WN), Where (WR), How (HW), Why (WY), What Effect (WE), What Condition (WC), What Attitude (WA), What Change (WG) and What Judgment (WJ).

\subsection{Previous Studies on Discourse Information Function}

$\mathrm{Du}$ (2009) proposes that the courtroom participants take interests as their central concern and accordingly select questions and answers, organize information, and attain their specific communicative objectives. The study shows that the objectives can be classified into three categories in light of its functions in courtroom discourse, namely, subjective category, objective category and explanatory category of discourse information. And these three categories of discourse information may help participants to make claims or counterclaims, provide basis for litigation, ensure reasonableness of their interest appeal and help the judge to define facts and disputes of lawsuits.

\section{Research Questions and Research Methodology}

\subsection{Research Questions}

In order to achieve the research objective of exploring how the discourse information functions work in the interest contention of courtroom trials concerning business dispute settlement, the following three research questions will be answered:

1) What kinds of discourse information functions are used in the data?

2) What kinds of discourse information units are used to realize each kind of discourse information function?

3) How does the specific discourse information function work?

\subsection{Research Methodology}

The present study adopts a combination of qualitative research method and the corpus research method, including the discourse analysis and Discourse Information Analysis (DIA) methods for the data analysis with the assistance of the corpus CLIPS (the Corpus for the Legal Information Processing System).

\subsection{Data Collection}

In order to guarantee the reliability and validity of the study, all the data are extracted from CLIPS (the Corpus for the Legal Information Processing System) which consists of transcripts of Chinese and American civil court trials. The data collected are mainly recordings of observed court proceedings, which were collected with professional digital voice recorders with the permission of the court and the consent of both parties (Ge, 2014). All of the discourses in CLIPS have been transcribed and tagged according to transcription and tagging conventions based on Discourse Information Theory (DIT).

\section{Discourse Information Function Features in Interest Contention of Business Dispute Settlement}

For the sake of striving for more interests respectively in the business dispute settlement, different information functions play different roles in interest contention. Du (2015) proposes that the communicative functions of discourse information include monologue, dialogue, and questioning (including questions $\&$ answers) and the selection of discourse information functions can be determined by the roles of the participants'. Since discourse information function is one of the main aspects of discourse information characteristics in interest contention, this section focuses on the features of discourse information function in interest contention in business dispute settlement.

\subsection{The Objective Category of Discourse Information Function}

In court hearings, the discourse information of objective category is used to present facts, provide evidence, offer background information of the case, etc. In the process of interest contention in business dispute settlement, the objective category of discourse information plays different functions to assist interest contention between the conflicting parties.

\subsubsection{Providing Participants' Identities Function}

In the process of business dispute settlement, the function of providing information on participants' identity lays 
legal guarantee and protection for both disputing parties' interest contention. Thus, the information concerning the participants' identities involved in the dispute is often provided at the beginning of court hearings regarding business dispute settlement.

As is illustrated in the following extract, this function of providing participants' identity is often realized by the judge's initiation by WT unit together with the disputing parties' information presentation by means of WF information units.

\section{Extract 1}

01[审判长]: <WT1>请坐。<WT2>现在核实双方 当事人身份。<WT3>原告向法庭报告你方公司名 称、住所地、法定代表人及职务、委托代理人及 代理权限。

02[原代一]: <WA1>好的。 $<\mathrm{WF} 1>$ 原告, 北京 $\times$ $\times \times \times$ 网络技术有限公司, 住所地: 北京市海淀 区 $\times \times \times x$ 。 $<W F 2>$ 法定代表人是刘 $X \times$, 是董 事长。代理人是两位, 我本人是北京 $x \times$ 律师事 务所律师, 赵 $\times$ 。旁边这位是公司的员工, 王 $\times$ 。 我们的权限详见授权委托书。

03[审判长]: 〈WT4>被告向法庭报告你方公司名 称、住所地、法定代表人及职务、委托代理人及 代理权限。

04[被代一] : <WA2>好。<WF3>被告一共有两

位。…...

$01[\mathrm{~J}]:<\mathrm{WT} 1>$ Please have a seat. $<\mathrm{WT} 2>$ Now verify the identity of the parties. <WT3 $>$ The plaintiff reports to the court the name, domicile, corporation aggregate and position of the company, the entrusted agent and the agency authority.

02[PA1]: <WA1>OK. <WF1 > The plaintiff, Beijing $x \times x \times x$ Network Technology Co., Ltd., Address: $\times x \times \times$ Haidian District, Beijing. <WF2>Liu $x x$ is the legal representative and the chairman of the board. There are two agents, I am a lawyer of Beijing $\times \times$ Law Firm, Zhao $x$ who seats next to me is the plaintiff company's employee, Wangx. Please refer to the authority of our power of attorney.

03[J]: <WT4>The defendant reports the name, domicile, legal representative and position of the company, the entrusted agent and the agency authority to the court.

04[DA1]: <WA2>OK. <WF3>A total of two defendants. ...

As is shown, Extract 1 is concerned with the providing of information on the disputing parties' identities at the beginning of the court trials.

As can be seen, the judge initiates the checking of information regarding both disputing parties' identities by adopting units of WT1, WT2 and WT3. Then WF1 presents the name and location of the plaintiff's corporation and WF2 provides the information concerning the corporation aggregate and the plaintiff lawyers. It can be found that the combination of WT and WF units plays the function of providing participants' identities.

In respect to this providing participants' identity function, on the one hand, the judge's checking on the information can guarantee the accuracy and eligibility of the corporation aggregates of both disputing parties involved in the lawsuit.

On the other hand, this function may guarantee the execution of the verdict concerning the interest allocation after interest contention, because frequent change of the corporation aggregate or the corporation's name in the period of litigation may lead to the impossible execution of the court's verdict regarding interest arrangement for dispute settlement.

And therefore, this providing participants' identity function can provide legal guarantee to protect the proceeding and final execution of both disputing parties' interests to a great extent in the interest contention in business dispute settlement.

\subsubsection{Procedural Progression Function}

Compared with the subjective information units such as WA, WI and WJ, the information unit indicating WT is more inclined to be the discourse information of objective category. This procedural progression function can guarantee the promotion of interest contention in the court trials concerning business dispute settlement.

\section{Extract 2}

01[审判长]: <WT1>我宣布现在开庭, ...... $01[\mathrm{~J}]:<\mathrm{WT} 1>\mathrm{I}$ declare now it is in session, ...

02[审判长]：<WT2>下面进行法庭调 查,
02[J]:< WT2 $>$ Next, let's go to the stage of court investigation, ... 
03[审判长]: <WT3>法庭调查到此结束。下 面进行法庭辩论。根据双方当事人的诉辩主 张, 本案的争议焦点在于:

04[审判长]: 〈WT4>法庭辩论结束。现在询 问双方当事人愿意在法庭的主持下调解解 决本案纠纷, 原告?

05[审判长]: <WT5>下面由双方当事人进行 最后陈述。

06[审判长]: 〈WT6>今天的庭审到此结束。 庭审后, 双方当事人阅笔录无误后签字确 认，现在休庭。

As is shown in Extract 2, it is the chief judge that regulates the whole process of dispute settlement in the court hearings and goes through the opening of the court hearing, court investigation, court debate, until the close of the court trial.

In the court proceeding to settle business disputes, the chief judge uses WT information units (from WF1 to WF6) to play the function of regulation in interest contention in business dispute settlement.

In order to guarantee the successful development, equality and justice of interest contention between the plaintiff and the defendant, the chief judge usually regulates the court trial's proceeding. And it can be found that the speech turns are allocated equally to the plaintiff lawyer and the defendant lawyer by the chief judge. And this can guarantee the equal opportunities for both conflicting parties to play their interest contention in the courtroom trials.

\subsubsection{Presenting Evidence Function}

In order to justify or prove the lawyers' views on a certain disputing interest focus, the evidence presentation is needed. And this evidence presentation is mainly realized by means of the adoption of objective information units of WF, WB, WE, etc.

\section{Extract 3}

$01[$ 被代二]: ...... $<\mathrm{WB}>$ 根据这个图 片是被告的 CEO 林 $\times$ 和原告的关 联公司微 $\times \times$ 的老总曾 $\times \times$ 的微信 往来, $<\mathrm{WF}>$ 这个曾 $\times \times$ 说制订了新 的用户资料和关系使用办法，被告 公司需要把用户完善后的 profile 和 用户关系回写给微博, 才能继续使 用微博登录和用户数据。

01[DA2]: ...<WB $>$ According to this picture which is the record of the WeChat exchanges between the defendant's CEO Lin $\times$ and the plaintiff's affiliated company micro- $x \times$ 's CEO Zeng $x \times,\langle\mathrm{WF}\rangle$ this Zeng $x x$ has said that the way of using new user's information and relationships has been established, and the defendant's company needs to rewrite the improved users' profiles and user relationships back to the microblog, only in this way, the defendant's company can use the way of logging by means of microblog and the users' data.

In this extract, the statement is the extract of the defendant lawyer's evidence presentation at the stage of defining conflicts and interests.

As is shown, WB information unit is used to provide the evidence to justify several points: Firstly, the information unit of WB proves that the new way of using the users' information and relationships has been established. Secondly, the WB unit also testifies that the way of using users' information and relationships is different from the way which is adopted when the plaintiff and the defendant were in the relationship of cooperation at once. Thirdly, this WB information unit demonstrates that the plaintiff and the defendant are in competition in essence. And therefore, the WB information unit works as the objective basis to prove the evidence presented by the defendant. And the function of presenting evidence is played and realized with the assistance of adopting the unit of WB.

\subsubsection{Detailed Specification Function}

In the process of business dispute settlement, it is necessary to make a certain issue clear to define the conflicts and interests, or examine possible solutions, or test solutions, or evaluate solutions. And such kind of an issue is usually closely related to the interest focus of the business dispute. Thus, the detailed specifications on a certain issue are needed for both conflicting parties' interest contention.

Extract 4

01[被代二]: <WT>你把使用被告软件 01 [DA2]: $<\mathrm{WT}>$ You describe the process to login the defendant's 
以 $\times \times$ 微博账户登录的过程描述一 下。

02[证人]: <WF1 $>$ 恩。我是 14 年的 1 月份下载的被告软件, 当时是用微博 登录, 但是到了 $7 、 8$ 月份的时候, 就 微博登录不了了。<WF2>当时在用被 告登录的时候, 他会弹出来一个提示 页面, 提示我说是绑定 $\times \times$ 微博, 然 后需要就是他会把那个微博的数据导 到被告上，然后会同时分享到微博， 只有我授权确认了才能够进行下去登 录进被告。 software by means of $x \times$ microblog account.

02[WD]: <WF1 >Well. It was the January of 2014 that I downloaded the defendant's software. And I used the microblog account to login, but in July and August, the defendant's software couldn't be logined in by means of microblog account. <WF2>When I was logining the defendant's software, a prompt page popped up which suggested that I should bind to $x \times$ microblog, and then the data concerning $x x$ microblog would be imported to the defendant's software, and then the data would be also shares to the microblog, and the login in the defendan't software can be continued only after the confirmation was authorized by me.

In Extract 4, the interaction occurs between the defendant lawyer and the witness for the defense at the stage of defining interests and conflicts.

In this extract, the witness for the defense is present at the court trial based on the approval of the defendant's application for the presence of the witness for the defense. And the purpose of the testimony from the witness for the defense is to prove that the export of micro-blog's data to the defendant's software is based on the confirmation of the users by providing WF2 information unit. Only after the user's confirmation, the user can continue to login the defendant's software.

If this fact provided (WF1 and WF2) by the detailed description of the witness for the defense is accepted by the court, the behavior of exporting the micro blog's data to the defendant's software will not be regarded as the unfair competition behavior. And this will lead to the defendant's advantageous place to protect their interests.

It can be found that this detailed specification function is realized by the adoption of WF information units (WF1 and WF2) to make specific description. And this detailed specification function plays a key role in effecting interest contention.

\subsection{The Subjective Category of Discourse Information Function}

Apart from the above-mentioned assistance of the objective category of discourse information function for interest contention, the realization of each disputing party's interest appeals relies mainly on the subjective category of discourse information during the court trials concerning business dispute.

In interest contention for business dispute settlement, the subjective category of discourse information function works effectively on the perspectives of regulating interest contention proceeding, proposing views or standpoints, manifesting attitudes, and so on. And such kind of DI function of subjective category is mainly realized by the information units indicating WA, WI and WJ.

\subsubsection{Function of Proposing Views}

In order to make the dispute on interest foci clear, the subjective category of discourse information may play the function of proposing views with the assistance of information units of WA in the process of dispute settlement.

\section{Extract 5}

01[审判长]: $\langle\mathrm{WB}>$ 根据双方当事人在庭 前提交的双方证据的情况，<WA1>合议 庭认为双方证据实质涉及四个方面的内 容: 一、关于原告被告主体是否适格的证 据; 二、关于涉案侵权行为的证据; 三、 关于涉案文章 “震惊视频实录: 原告浏览 器泄露用户账户和密码” 是否客观、真实 的证据; 四、关于原告方合理支出的证据。 $<\mathrm{WA} 2>$ 对于上述归纳, 双方当事人是否 认可? <WA3>原告?

$$
\begin{aligned}
& \text { 02[原代一]: <WA4>认可。 } \\
& \text { 03[审判长]: }\langle\mathrm{WA} 5>\text { 被告? } \\
& \text { 04[被代二]: }\langle\mathrm{WA} 6>\text { 认可。 }
\end{aligned}
$$

01[J]: <WB $>$ According to the evidence submitted by both parties before the court, <WA1 $>$ the collegial panel thinks that the two parties' evidence in fact involves four aspects: Firstly, the evidence concerning whether the plaintiff and the defendant are the eligible subjects; Secondly, the evidence concerning infringement; Thirdly, the evidence concerning the objectivity and truth of relevant article entitled "Shocking Video Record: the plaintiff browser discloses users' accounts and passwords"; Fourthly, the evidence concerning the reasonable expenditure. <WA2>For the above summary, do both parties recognize? $<$ WA3 $>$ The plaintiff?

02[PA1]: <WA4> We recognize.

03[J]: <WA5 $>$ The defendant?

04[DA2]: <WA6>We recognize. 
As is seen, the interactions in Extract 5 mainly show the court's views on the summary of what essential aspects of the evidence are involved and both of the disputing parties' opinions on the court's previous summary at the stage of defining interests and conflicts.

In this extract, the court's proposal of views and both disputing parties' opinions are mainly realized by means of WA1, WA4 and WA6 information units respectively. In the process of business dispute settlement, the chief judge has the responsibility to promote the proceeding of the court hearing, so the court's proposal of this summary on evidence promotes the dispute settlement to continue.

Moreover, the court's summary on the essential content of the evidence is closely related to the following proceeding of evidence presentation and evidence challenging which effects both disputing parties' interest contention. This is the reason why the chief judge inquires both parties' opinions on the court's summary; therefore, only after the both parties' confirmation in the court's summary, the present and following interest contention of both parties' can be promoted to proceed fairly and successfully.

\subsubsection{Function of Elaborating Attitudes}

After the views or attitudes concerning interest contention are proposed by the participants involved in the court hearing on business dispute, the participants often make more detailed elaboration of previous views or attitudes. This makes the views or attitudes sound more reasonable and the views or attitudes would be accepted more easily by the court.

\section{Extract 6}

01[MR. LOY]: <WA1>Mr. Chief Justice, and may it please the Court: The standing trust for antitrust adopted by this Court 30 years ago in AGC is the appropriate test to give effect to Congress's intent under the Lanham Act, and this is for three reasons. <WA2>First, the plain text of the Lanham Act at Section 45 states that the intent of that Act is to protect commercial actors against unfair competition. Competition generally is the focus of both antitrust statutes and the Lanham Act, and any test that this Court adopts should be tied to that statutory intent section. <WA3>Second, the history in the common law of both antitrust statutes and the Lanham Act are similar. $<$ WF $>$ In fact, in the Lanham Act context, the common law was more specific and more direct than it was under the antitrust statutes. <WA4>And, finally, each of the five...

In Extract 6, it is a lawsuit concerning advertisement dispute between two incorporated companies. And Mr. Loy is the lawyer on behalf of the petitioner.

In this extract, the petitioner lawyer proposes the views which are favorable for the petitioner's interest contention at the very beginning of the court trial to settle the advertisement dispute by means of WA information units (from WA1 to WA4).

After that, in order to persuade the court to accept the views representing the petitioner, the petitioner lawyer elaborates their attitudes by the following three reasons. And the three reasons are realized by means of WA2, WA3, WF, and WA4 units, which helps to enhance the persuasive power of the previous views in WA1 and increase the possibility to be accepted by the court. In this way, this function of elaborating attitudes helps the participants involved in the dispute settlement to stay in an advantageous position for interest contention.

\subsubsection{Function of Regulation}

Although the regulation of information seems not to be the main part of interest contention, this function lays sound foundation for the smooth proceeding of interest contention and plays its unique and indispensable function in interest contention of business dispute settlement.

In the court trials concerning business dispute, the development of interest contention in dispute settlement depends on the participants' manipulation of discourse information. And the discourse information may play different functions owing to the different roles of the participants.

Apart from the above-mentioned usage of WT information unit to play the procedural progression function of the objective category, the chief judge plays this regulatory function by means of the subjective information unit indicating WA.

In such kind of situations, the chief judge's regulations are usually accompanied with some multimodal resources, such as the interruptions to the plaintiff's attorney or the defense attorney. For example,

\section{Extract 7}

$01[$ 被代二]: ...... $<$ WA1 $>$ 然后我会就证据 9 的质证 意见是
01[DA2]: ... $<$ WA1 $>$ Then my views on challenging evidence 9 is that 
02[被代一]: 〈WA2> (轻声) 我来吧

03[审判长]: <WA3> (打断) 抓紧时间!

04[被代一]: 〈WA4>我说一下......
02[DA1]:<WA2> (softly) Let me make the statement.

$03[\mathrm{~J}]:<$ WA3 $>$ (interruption) Hurry up!

04 [DA1]:<WA4>What I want to say is that ...

In Extract 7, the defendant lawyer is interrupted by the chief judge when he is beginning to make views on challenging evidence 9. In the court hearing, the chief judge has the responsibility to regulate the successful and effective proceeding of the court trials. And therefore, the defendant lawyer is interrupted to be hurry when he is found that he is relatively slow to make his statements.

In this extract, if the defendant lawyer makes his statement at this relatively low speed, it may help the defendant lawyer to get more time to organize his thoughts and make more rigorous persuasion in evidence challenging.

However, this relatively slow behavior means the occupation of the counterparty's time for arguments for interest contention, so it is indispensable for the chief judge to interrupt and to allocate the speech turns to both disputing parties equally in the court trials on business dispute settlement.

Besides, in such kind of regulation, WA information units are often adopted by the chief judge to guarantee the smooth progression of the court trials to settle the business dispute.

\subsection{The Expositive Category of Discourse Information Function}

Apart from the objective and subjective categories of discourse information functions, the expositive category of DI functions works when certain issues or points need to be identified or interpreted further.

\subsubsection{Further Explanation Function}

This further explanation function is often closely related to the key points influencing the final chief judgment on interest allocation in business dispute settlement.

In the following Extract 8, the utterance is the chief judge's question to the witness for the defense for seeking what kind of personal information and friend information can be seen when the witness for the defense uses the defendant's software. And this utterance occurs at the stage of defining interests and conflicts.

As is seen, the second WF information unit is the further explanation of the first WF unit. And the specific time is emphasized by the chief judge by means of this further explanation. This is because the personal information and friend information which has been asked by the chief judge is one of the important evidence to make the following judgment on interest foci summary and the final decision on the verdict to allocate the interests to both disputing parties.

\section{Extract 8}

01[审判长]: <WF1 $>$ 你还记得你刚开始使用 被告软件的时候你可以看到 $\times \times$ 微博哪些个 人信息和好友信息? $<\mathrm{WF} 2>$ 在 14 年 $7 、 8$ 月 份之前你在使用被告软件的时候你可以看到 $\times \times$ 微博的哪些个人信息和好友信息?

01[J]: <WF1>Can you remember what personal information and friend information of $x \times$ microblog when you start to use the defendant's software? <WF2>What kind of personal information and information concerning friends of $x x$ microblog can you see when you use the defendant's software before the July and August of 2014?

In addition, this personal information and information concerning friends disclosed on the defendant's software is different before and after the July and August of 2014, so the chief judge emphasizes the time for further explanation of the previous WF information unit.

\subsubsection{Function of Making Further Confirmation}

In order to ensure the equality and justice of the final judgment concerning interest arrangement to both conflicting parties, the court needs to make further confirmation on certain important issues, which can provide reference for the decision on the final verdict making.

\section{Extract 9}

[审判员]: <WT >你今天到庭，你再明 确一下你要证明的事项是什么?

[证人]: 〈WF $>$ 证明的就是我在下载、 使用被告软件的时候用 $\times \times$ 微博登录, 他会有提示我需要授权才可以使用。
[J']: $\langle\mathrm{WT}>$ Since you are present at the court trial today, can you identify what you want to prove clearly again?

[WD]: <WF $>$ What I want to prove is that the micro blog will remind me that I can continue the usage of the defendant's software only after my confirmation when I download the defendant's software and use the micro blog to login it. 
In Extract 9, it is the judge's further confirmation about what the witness for the defense wants to prove. And the witness for the defense is present after the court's approval of the defendant's application. WT unit starts the judge's further confirmation by asking the witness for the defense that can you identify what you want to prove clearly again. What the witness for the defense wants to testify is that the defendant's software can be used when she logins the defendant's software only after her confirmation in WF unit. It can be found that the testimony of witness for the defense in fact helps the defendant to shirk the responsibility of obtaining the plaintiff's users' data.

In this way, if the testimony from the witness for the defense is accepted by the court, this indicates that it is hard for the plaintiff to make up their losses and it helps the defendant to avoid their great losses in this dispute settlement.

Owing to the importance of the testimony from the witness for the defense, the judge makes the further confirmation for the testimony to guarantee the justice and equality of the following judgment for the settlement of this unfair competition dispute.

\subsection{The Compound Category of Discourse Information Function}

Apart from the above-mentioned categories of discourse information functions, there is another kind of DI function of compound category which serves for interest contention in the court hearing.

The reason why it is called the compound category lies on that this category incorporates not only one type of function together. For example, the compound category can incorporate the objective category and subjective category, however, this category of DI function works as a whole itself.

In addition, this compound category of discourse information function is often used to serve for the persuasion in interest contention in the court trials concerning business dispute.

\section{Extract 10}

01[原代二]: ...... $<\mathrm{WF} 1>$ 被告在经营 $\times \times \times$ 网 站和 $\times \times \times$ 网站的过程中, 继续通过网站提 供涉案侵权文章的链接, $\langle\mathrm{WF} 2\rangle$ 在 $\times \times$ 网站 头条搜索链中, 搜索 “原告汶览器窃取用户 密码”, 在搜索结果的头条出现 $\times \times$ 网站这 篇涉案虚假报道的链接行为, $\langle\mathrm{WA}\rangle$ 该涉案 虚假报道属于侵权行为。

01[PA2]: ... <WF1> In the operation of $x \times$ site and $\times \times \times$ website, the defendant continues to provide the link of the infringing article involved in the case. <WF2> To search the content of "the plaintiff's browser steals users' passwords" in the search chain of $x \times$ website, the link of infringing article involved in the case can be found in the headline of the search results, <WA $>$ this false news report involved in this case belongs to the infringement behavior...

This utterance is part of the plaintiff lawyer's litigation appeals at the very beginning of court investigation before interests and conflicts are defined.

As is seen, although the previous two propositions are the fact presentation by the use of two WF units, the proposition of WA unit is in essence the emphasis of the plaintiff lawyer's statement.

The previous uses of the objective category of DI function help to increase the objectivity and decrease the subjectivity of the plaintiff lawyer's statement by means of WF information units of WF1 and WF2. And the WA unit sounds more reasonable and persuasive based on the previous two WF information units (WF1 and WF2).

In this way, the two kinds of the subjective and objective categories of DI functions work together to try to attain the effect of rationality and reasonability.

\section{Extract 11}

$01[$ MR. $\times x$ ]: $<2,1,3,1$, WA1 $>$ Mr. Chief Justice, and may it please the Court: ..., and this is for three reasons. $\langle 3,1,4,1$,WA2 $>$ First, $<4,1,5,1, \mathrm{WF} 1\rangle$ the plain text of the Lanham Act at Section 45 states that the intent of that Act is to protect commercial actors against unfair competition. $\langle 4,1,5,2$,WF2 $>$ Competition generally is the focus of both antitrust statutes and the Lanham Act, $<4,1,5,3$,WA5 $>$ and any test that this Court adopts should be tied to that statutory intent section. $<3,1,4,2$,WA3 $>$ Second, $\ldots .<3,1,4,3$,WA4 $>$ And, finally, $\ldots$

In Extract 11, the utterance is concerned with part of the petitioner lawyer's litigation appeal of an advertisement dispute and Mr. $\times \times$ in the extract is the lawyer on behalf of the petitioner.

As is shown, WA1 is the petitioner lawyer's general litigation appeal and their views on the choice of more appropriate law or statute which is used as the legal basis to make the verdict for the dispute settlement. And WA2, WA3, and WA4 are the further explanations of WA1. Among these further explanations, in respect to WA2, its realization belongs to this compound category of DI function. 
To be specific, in WA2 information unit, WF1 shows the intent of the Lanham Act, WF2 states that competition is the common focus of both antitrust statutes and the Lanham Act. Based on the objective category of WF1 and WF2, WA5 proposes that any test that this Court adopts should be tied to that statutory intent section.

In this way, the compound category of WA2 works with the assistance of the general effect of the uses of WF1, WF2 and WA5 units together. Moreover, it can be found that this compound category function often works on the basis of the incorporation of objective discourse information with subjective discourse information.

\section{Conclusion}

The present study focuses on the analysis of the features of discourse information functions and how they work in the interest contention of courtroom trials concerning business dispute settlement. From the data analysis, new findings have been found out in the present study. Apart from the objective, subjective, and expositive categories of discourse information functions in courtroom interactions (Du, 2009), a new discourse information function, namely, the compound category, has been found out in business dispute settlement. More specifically, it can be found that the discourse information functions can be classified into four categories, namely, the objective category, the subjective category, the expositive category and the compound category in interest contention of courtroom discourses concerning business dispute settlement. More specifically, the objective category of discourse information function often works by means of WF and WB information units. WA and WI information units usually work as the nucleus information to manifest the lawyers' interest appeals. The expositive category of discourse information function is often realized by means of WF information units. The compound category is frequently used by lawyers to strengthen their views or to persuade the court to accept their opinions in interest contention. The use of a certain kind of information unit or the combinations of different information units works together to play different discourse information functions in the interest contention of the courtroom discourses concerning business dispute settlement.

\section{Author biography}

Tingting Guo received her PhD in Business English Studies from GuangDong University of Foreign Studies. Her research interests include discourse analysis, business communication studies, forensic linguistics and comparative study of English and Chinese. She currently works in the Postdoctoral Research Station of Chinese Language and Literature of School of Liberal Arts of Zhengzhou University.

\section{Acknowledgments}

The research is sponsored by Ph. D Research Programme of Zhongyuan University of Technology [No. 34110495], Philosophy \& Social Science Planning Project of Henan Province [No. 2019BYY020], and the 13th Five-year Key Project Cultivation Programme of School of Foreign Languages of Zhongyuan University of Technology. The present research is a partial fulfillment of a joint training postdoctoral program between Zhongyuan University of Technology and Zhengzhou University.

The author's sincere appreciation goes to the anonymous peer-reviewers and the editor for their comments on the revision of this article. And my heartfelt gratitude also goes to the assistant editor for her timely mail confirmation and supply of help. I am solely responsible for any remaining errors and shortcomings.

\section{References}

Adrian, J. J. (1988). Construction claims: A quantitative approach. Reston Publishing Company.

Brown, G., Gillian, B., \& Yule, G. (1983). Discourse analysis. Cambridge University Press.

Chen, J. (2011). The reconstruction of prosecution-defence-judge relationship in China: A frame analysis of judges' discourse information processing. International Journal of Speech, Language \& the Law, 18(2). https://doi.org/10.1558/ijsll.v18i2.309

Chen, J. (2017). Chunks in Information Flow: A Corpus-based Analysis of Legal Discourse. Rule of Law, Courtroom Procedures, 1.

Conley, J. M., \& O’Barr, W. M. (1998). Just words: Law, language, and power. Chicago: The University of Chicago Press.

Cotterill, J. (2003). Language and power in court: A linguistic analysis of the OJ Simpson trial. Springer. https://doi.org/10.1057/9780230006010

$\mathrm{Du}$, J. (2007). A study of the tree information structure of legal discourse. Modern Foreign Languages (Quarterly), 30(1), 40-50.

$\mathrm{Du}$, J. (2009). A study of the functions of courtroom questioning and answering and participants' communicative 
objective attainment [J]. Modern Foreign Languages (Quarterly), 32(4), 360-368.

Du, J. (Ed.). (2013). Discourse analysis. Wuhan: Wuhan University Press.

Du, J. (2015). On legal discourse information. Beijing: People's Publishing House.

Fairclough, N. (1995). Critical discourse analysis: The critical study of language. New York: Longman Publishing.

Fan, Y. (2007). Theory and practice of dispute resolution. Beijing: Tsinghua University Press.

Ge, Y. (2014). Resolution of conflict of interest in Chinese civil court hearings: A perspective of discourse information theory. International Journal of Speech Language and the Law, 21(1), 163-168. https://doi.org/10.1558/ijsll.v21i1.163

Guan, X. (2015). Potential speaker-discriminating power of speaking style: Application of discourse information analysis to forensic speaker recognition. International Journal of Law, Language \& Discourse, 5(1), 38-65.

Guo, T. T. (2017). A study on interest contention in business dispute settlement: A discourse information approach. Unpublished doctoral dissertation, Guangdong University of Foreign Studies, Guangzhou, China.

Guo, T. T., \& Zhao, Z. X. (2019). The discourse analysis of e-business instant communication from the perspective of Politeness Principle. International Journal of English Linguistics, 9(2), 174-188. https://doi.org/10.5539/ijel.v9n2p174

Guo, T. T., Zhao, Z. X., \& Han, X. H. (2019). The discourse analysis of social factors influencing interest contention in business dispute settlement: A perspective of discourse information theory. Asian Social Science, 15(3), 46-57. https://doi.org/10.5539/ass.v15n3p46

Guo, T. T. (2019). The Discourse Analysis of Psychological Factors Influencing Interest Contention in Business Dispute Settlement: A Perspective of Discourse Information Theory. International Journal of English Linguistics, 9(3), 176-187. https://doi.org/10.5539/ijel.v9n3p176

Guo, T., \& Zhu, W. (2009). The integrative nature of BE teaching: Knowledge and skills. Asian Social Science, 5(11), 72-75. https://doi.org/10.5539/ass.v5n11p72

Harmon, K. M. J. (2003). Resolution of Construction Disputes: A Review of Current Methodologies. Leadership and Management in Engineering, 3(4), 187-201. https://doi.org/10.1061/(ASCE)1532-6748(2003)3:4(187)

Huai, Y. M. (2014). A procedure research on the production and construal of communicative intention from a multimodal discourse information processing perspective. Foreign Language and Literature, 30(3), 90-95.

Huang, Y. P. (2012). A discourse analysis of lawyer information manipulation in Chinese criminal trials. Unpublished doctoral dissertation, Guangdong University of Foreign Studies, Guangzhou, China.

Loosemore, M., Nguyen, B. T., \& Denis, N. (2000). An investigation into the merits of encouraging conflict in the construction industry. Construction Management and Economics, 18(4), 447-456. https://doi.org/10.1080/01446190050024860

Pan, X., \& Du, J. (2011). Information flow of process control in courtroom question and response. Journal of Foreign Languages, (2), 56-63.

Rubin, R. A., Fairweather, V., \& Guy, S. (1999). Construction Claims: Prevention and Resolution. New York: John Wiley \& Sons.

Sorenson, R. L. (1999). Conflict management strategies used by successful family businesses. Family Business Review, 12(4), 325-339. https://doi.org/10.1111/j.1741-6248.1999.00325.x

Spencer-Oatey, H., \& Xing, J. (2004). Rapport management problems in Chinese-British business interactions. Multilingual Communication, 197-222. https://doi.org/10.1075/hsm.3.13spe

Sun, B. (2016). A study on automatic information seeking in Chinese judicial discourse. Unpublished doctoral dissertation, Guangdong University of Foreign Studies, Guangzhou, China.

Sun, B., \& Guo, T. (2017). A corpus-based study on information features of Chinese judicial discourse. Journal of Zhongyuan University of Technology, 28(5), 13-18.

van Dijk, T. A. (2008). Discourse and context: A Socio-cognitive approach. Cambridge: Cambridge University Press. https://doi.org/10.1017/CBO9780511481499

Vestergaard, B., Helvard, E., \& Sørensen, A. R. (2011). Conflict resolution: Working with conflicts. Denmark: Danish Centre for Conflict Resolution. 
Wang, H., \& Ge, Y. F. (2020). Negotiating national identities in conflict situations: The discursive reproduction of the Sino-US trade war in China's news reports. Discourse \& Communication, 14(1), 65-83. https://doi.org/10.1177/1750481319893406

Wodak, R. (1985). The interaction between judge and defendant. In T. A. van Dijk (Ed.), Handbook of Discourse Analysis (vol. 4: Discourse Analysis in Society, pp. 181-191). London: Academic Press. Harris, 1989

Xu, Y. P. (2013). Realization of persuasion in Chinese court conciliation: The discourse information approach. Beijing: Science Press.

Yang, W. H. (2009). A discourse analysis of interpersonal business negotiations. Beijing: Science Press.

Yuan, C. Y. (2018). A battlefield or a lecture hall? A contrastive multimodal discourse analysis of courtroom trials. Social Semiotics, 1-25. https://doi.org/10.1080/10350330.2018.1504653

Yue, S. W. (2016). Effective information exchange during conflict management in business meetings. Unpublished doctoral dissertation, Guangdong University of Foreign Studies, Guangzhou, China.

Zhang, S. M. (2016). Authorship attribution and feature testing for short Chinese emails. International Journal of Speech, Language \& the Law, 23(1). https://doi.org/10.1558/ijsll.v23i1.20300

Zhao, J. F. (2011). On the information structure and its linguistic realizations in legal discourse: A Chinese-English contrastive discourse analysis. Beijing: Science Press.

Zhong, C. S. (2009). A discursive-psychological study of judges' judicial behavior. Unpublished doctoral dissertation, Guangdong University of Foreign Studies, Guangzhou, China.

\section{Copyrights}

Copyright for this article is retained by the author(s), with first publication rights granted to the journal.

This is an open-access article distributed under the terms and conditions of the Creative Commons Attribution license (http://creativecommons.org/licenses/by/4.0/). 